\title{
Role of cyclopoid copepods Oithona spp. in North Sea plankton communities
}

\author{
Torkel Gissel Nielsen" ${ }^{1}$, Marina Sabatini ${ }^{2}$ \\ ${ }^{1}$ National Environmental Research Institute, Department of Marine Ecology and Microbiology, Frederiksborgvej 399 \\ PO Box 358, DK-4000 Roskilde, Denmark \\ ${ }^{2}$ Instituto Nacional de Investigación y Desarrollo Pesquero, INIDEP, CC 175, Playa Grande, Mar del Plata, Argentina
}

\begin{abstract}
Copepod production was investigated in the North Sea, with special emphasis on the trophodynamic role of the cyclopoid copepod Oithona similis. During a cruise in May-June 1992, no significant correlation was found between the specific egg production rate (SEP) of Oithona spp. and available food. However, $O$. similis SEP was positively correlated to the protozooplankton, in contrast to the co-occurring calanoid Paracalanus parvus SEP which was significantly correlated to the chlorophyll a concentration. In the shallow Dogger Bank region Oithona spp. contributed 50 and $70 \%$ of the total copepod biomass and production, respectively. In the northern regions dominated by Calanus spp. Oithona's contribution to biomass and production decreased to about 10 and $20 \%$, respectively. These regional differences were confirmed by analysis of seasonal data, in which Oithona spp. contributed 40 and $13 \%$ of the annual copepod production in Dogger Bank and the northern regions, respectively. Biomass and production of Oithona spp. show little temporal and spatial variation as compared to calanoids. When calanoid populations are low or in shallow environments where eggs of the freespawning calanoid are lost to the benthos, Oithona is an important component of the food web.
\end{abstract}

KEY WORDS: Cyclopoid copepod - Oithona spp. Fecundity Production - North Sea

\section{INTRODUCTION}

Studies of copepod demography, production and the role of copepods in carbon cycling have until recently, focused on the larger species (mainly calanoid copepods). This bias arises from the widespread use of nets with a mesh size of $200 \mu \mathrm{m}$ as recommended by UNESCO (1968), which undersample smaller copepod species (i.e. most cyclopoids). For example, the Continuous Plankton Recorder (CPR) data from the North Sea were collected with a $270 \mu \mathrm{m}$ mesh, so this unique material cannot be used for quantifying populations of the small copepod species, e.g. Oithona spp. (Fransz et al. 1991). Recent studies, however, have documented that Oithona spp. can contribute significantly to copepod biomass in temperate seas, such as the North Sea and adjacent waters (Hay et al. 1991, Nielsen et al. 1993, Kiørboe \& Nielsen 1994). As the potential impor-

\footnotetext{
•E-mail: hmtgn@dmu.dk
}

tance of Oithona spp. has become evident, methodological difficulties have arisen. The currently used in situ techniques for measurement of calanoid production are not suitable for the small egg-carrying cyclopoid copepods. Thus, small cyclopoids of the genus Oithona are often mentioned among the dominating species, but are not included (e.g. Peterson et al. 1991), or are treated as calanoids in estimates of copepod grazing pressure and secondary production (e.g. Peterson et al. 1991. Nielsen et al. 1993, Kiørboe \& Nielsen 1994). As a consequence, little information about the actual contribution of Oithona spp. to secondary production is available at present (Tremblay \& Roff 1983, Roff et al. 1988, McLaren et al. 1989, Fransz \& González 1995).

Much less is known about the role of cyclopoids in planktonic communities. It has been suggested that small phytoplankton $(<5$ to $10 \mu \mathrm{m})$, which are inefficiently grazed by the larger calanoid copepods, may support feeding and egg production in Oithona spp., resulting in a different spatio-temporal pattern 
of production between calanoid species and Oithona spp. (Sabatini \& Kiørboe 1994). Several recent studies have stressed their potential role in microbial food webs (González \& Smetacek 1994. González et al. 1994).

The Dogger Bank in the southern North Sea is well known for its productive fisheries (Daan et al. 1990). This may be related to the occurrence of fronts with enhanced 'new' production in the region, that leads to a short 'classical' type of food chain (Munk 1993, Nielsen et al. 1993, Munk \& Nielsen 1994). Since Oithona spp. are found at high concentrations in these areas (Nielsen \& Richardson 1989, Nielsen et al. 1993), interest has developed to understand their role in a copepod community that is able to support a large fishery. Potentially, Oithona spp. play an important role, since they are quantitatively important food items of fish larvae including cod and haddock (Kane 1984), herring (Cohen \& Lough 1983) and anchovy (Kuwara \& Suzuki 1984, Mitami 1988, Vinas \& Ramírez in press). In particular, Oithona similis appears to be a crucial transitional prey for pollock larvae when feeding habits shift from copepod nauplii to larger zooplankton (Nishiyama \& Hirano 1985). Euphausids (e.g. Gibbons et al. 1991), chaetognaths (Øresland 1990) and some calanoid copepods (e.g. Ohtsuka et al. 1987, Hopkins \& Torres 1989) also are known to feed on cyclopoid copepods, mainly Oithona spp.

The aims of this investigation are: (1) to estimate the in situ egg production of Oithona and its contribution to copepod production; (2) to examine the relationship between fecundity/production and food availability of Oithona spp. and calanoids; and (3) analyse the spatiotemporal importance of Oithona in comparison with the co-occurring calanoid copepods.

\section{MATERIALS AND METHODS}

Study site. This investigation was conducted in the North Sea from May 22 to June 3, 1992 with the research vessel 'Dana' (Danish Fisheries Ministry). Sampling was performed along 3 transects (Fig. 1).

Water column structure. At all stations profiles of temperature, salinity and fluorescence were recorded throughout the water column using a Neil Brown Mark III CTD system and a Q-instrument fluorometer (Hundahl \& Holck 1980). The fluorescence was converted to chlorophyll from a linear regression between the fluorescence and several spectrophotometric measurements of chlorophyll (chl a) covering all 3 transects (chl $a=0.015 \times$ Fluo $-0.217, r^{2}=0.92, n=112$ ) From the vertical structure of the water column 5 or 6 depths were selected for chemical and biological measurements.

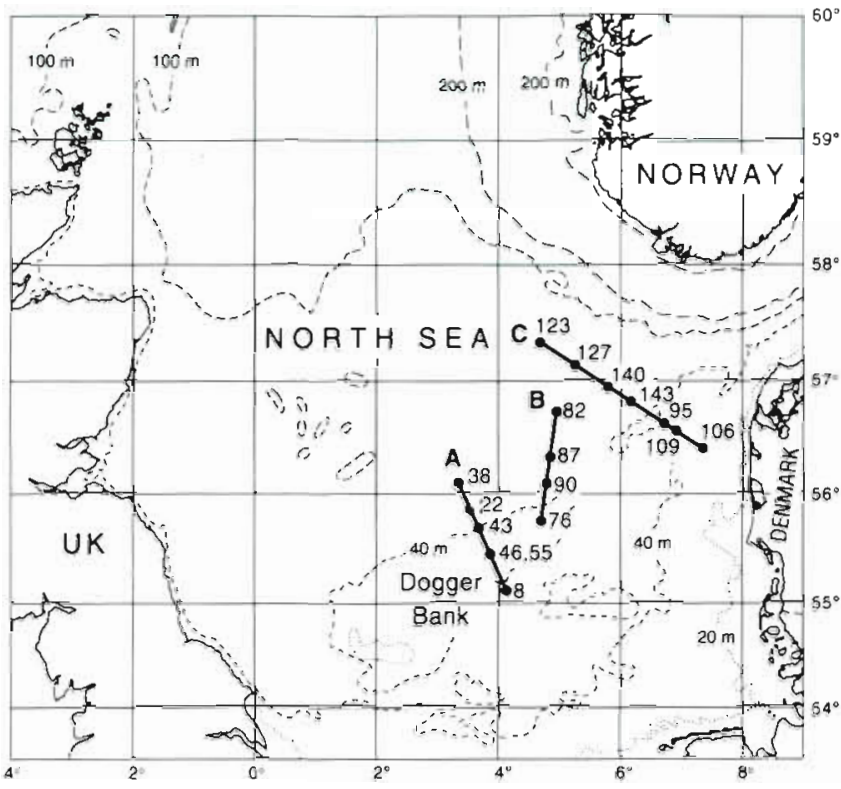

Fig. 1. Map showing the area investigated and the approximate positions of stations

Potential copepod prey. Samples for chl a were taken at 3 to 5 depths per station. 1 or 2 I were filtered onto GF/F filters, extracted in $90 \%$ acetone and measured spectrophotometrically (Strickland \& Parsons 1972). Integrated values of chlorophyll were calculated from the fluorescence profiles and the regression to $\mathrm{chl}$ a. The relative size distribution of the phytoplankton in the surface and at the subsurface fluorescence maxima along Transect $\mathrm{A}$ was measured fluorometrically. Duplicate samples were filtered on to $25 \mathrm{~mm}$ GF/F, $3 \mu \mathrm{m}$ Nuclepore and 11 and $50 \mu \mathrm{m}$ Nitex filters and extracted in $96 \%$ ethanol (Jespersen \& Christoffersen 1987).

Samples for enumeration of phyto- and protozooplankton (100 ml) were fixed in $1 \%$ acid Lugol's solution and counted after $24 \mathrm{~h}$ sedimentation using an inverted microscope. Depending on the abundance of the species in consideration a fraction or the total $50 \mathrm{ml}$ subsample was counted. Biovolume was estimated from measurements of linear dimensions assuming simple geometrical shapes and a conversion factor of $0.11 \mathrm{pg} \mathrm{C} \mu \mathrm{m}^{-3}$ for ciliates and naked dinoflagellates

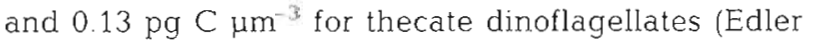
1979). The depth integrated biomass was estimated from discrete samples by trapezoidal integration.

Copepod biomass. Copepod biomass was determined at all stations. Sampling was carried out at 2 depth strata: above and below the fluorescence peak, if present, or below the thermocline. Samples were collected by a submersible pump (1200 $\left.1 \mathrm{~min}^{-1}\right)$ equipped with $30 \mu \mathrm{m}$ mesh size net that was raised at $10 \mathrm{~m} \mathrm{~min}^{-1}$ through the layer The samples were preserved in $2 \%$ 
buffered formalin. Zooplankton were later identified and counted. In the case of copepods, at least 400 individuals were classified into eggs, nauplii, copepodites, females and males. Abundance data for copepods were converted to biomass by means of length-weight regressions cited in Kiorboe \& Nielsen (1990) and Sabatini \& Kiorboe (1994). Egg carbon was assumed to be $0.14 \mathrm{pg} \mathrm{C} \mathrm{mm}^{-3}$ (Kiørboe et al. 1985, Huntley \& Lopez 1992).

Egg production. Calanoid copepod egg production was estimated according to Kiørboe et al. (1985). Females were gently sampled from the thermocline to the surface using a WP-2 net $(200 \mu \mathrm{m})$ with a large cod end. Immediately after collecting fertilized femaies were added to $600 \mathrm{ml}$ bottles (1 to 5 female bottle ${ }^{-1}$ ) with $180 \mu \mathrm{m}$ screened surface water. Along Transect $A$ additional experiments were conducted with females sampled at the subsurface fluorescence maximum, if present, or below the thermocline. Depending on female abundance, up to 6 replicate bottles were incubated at in situ temperature for $24 \mathrm{~h}$. Females from the surface mixed layer and the subsurface fluorescence maximum were incubated at 12 and $7^{\circ} \mathrm{C}$, respectively. At the end of incubation, spawned eggs were counted. Samples for Oithona spp. egg production (egg:females ratio) were taken at discrete depths throughout the water column using a $30 \mathrm{l}$ water bottle. On deck each sample was concentrated on a submerged filter (45 $\mu \mathrm{m}$ ) and then preserved in $2 \%$ buffered formalin. At this stage handling was gentle in order to avoid damages or detachment of egg sacs from the females. Adult females and total number of eggs within each sac were counted in subsamples (or total samples when eggs were scarce); normally $>400$ eggs and all the females present in the same subsample were counted. Cephalothorax lengths of about 10 females were measured for each sample to estimate female carbon biomass from length carbon regression in Sabatini \& Kiorboe (1994).

Population specific egg production rates (SEP, $\mathrm{d}^{-1}$ ) of Oithona spp. were calculated from the ratio of eggs to females $(E / F)$, temperature-dependent hatching rates $\left(H R, d^{-1}\right)$, and carbon content of the eggs and females:

$$
\mathrm{SEP}=(\mathrm{E} / \mathrm{F}) \mathrm{HR}(\operatorname{egg} \mathrm{C} / \mathrm{femaleC})
$$

The hatching rate (HR) at the surface temperature was measured on board in incubations at in situ temperature. Egg-carrying females (80) collected at Stn 38 were placed individually in $62 \mathrm{ml}$ cell culture screwcap flasks filled with $45 \mu \mathrm{m}$ screened surface water and incubated at $12^{\circ} \mathrm{C}$. Every $12 \mathrm{~h}, 10$ to 20 females were preserved and the eggs and nauplii counted. The average hatching rate was then estimated from the slope of the regression of hatching $\%$ \{[no. of nauplii/(no. of eggs + no, of nauplii) $] \times 100\}$ versus time. The obtained rate was $0.93 \% \mathrm{~h}^{-1}$ or $0.223 \mathrm{~d}^{-1}$, which is about the same as predicted by the temperature-dependent equation,

$$
\operatorname{HR}\left(d^{-1}\right)=0.0604 e^{0.113 T}
$$

Hatching rates at any other temperature were thus estimated from Eq. (2) (Sabatini \& Kiørboe 1994),

Copepod production. Copepod production was calculated from depth integrated biomass and measured specific egg production rate by assuming equal specific egg production and juvenile growth rate (Berggreen et al. 1988). All the species were included in the calculation to estimate total production. To those species for which no fecundity data were available, the average specific egg production of the other species (excluding Oithona) was applied.

Annual copepod production. In order to estimate the contribution of Oithona spp. to the standing stock and secondary production of copepods in the North Sea on an annual basis, the results of the present cruise were used in conjunction with literature data covering all seasons (Table 1). Unfortunately no Oithona egg:female ratios were available from the months of January and October. Production rates for these months were then calculated from the average of weight-specific egg production in August-September and FebruaryMarch, respectively.

\section{RESULTS}

\section{Water column structure}

High solar radiation, clear skies and low wind during the study period increased the stability of the water column, so that even the shallow water over Dogger Bank was thermally stratified. A thermocline at 10 to $20 \mathrm{~m}$ depth separated $12^{\circ} \mathrm{C}$ surface water from $7^{\circ} \mathrm{C}$ bottom water (Fig. 2). The water column along Transects $\mathrm{A}$ and $B$ was almost vertically isohaline and salinities less than $35 \%$ were only recorded south of the Dogger Bank.

Table 1 Sources of data for the annual pattern of copepod biomass and production shown in Fig. 9

\begin{tabular}{|lrl|}
\hline Month & Year & \multicolumn{1}{c|}{ Source } \\
\hline January & 1988 & Hay et al. (1991) \\
February/March & 1988 & Nielsen \& Richardson (1989) \\
May/June & 1990 & Nielsen et al. (1993) \\
May/June & 1992 & This study \\
August/September & 1991 & Munk \& Nielsen (1994) \\
October & 1987 & Hay et al. (1991) \\
December & 1987 & Hay et al. (1991) \\
\hline
\end{tabular}



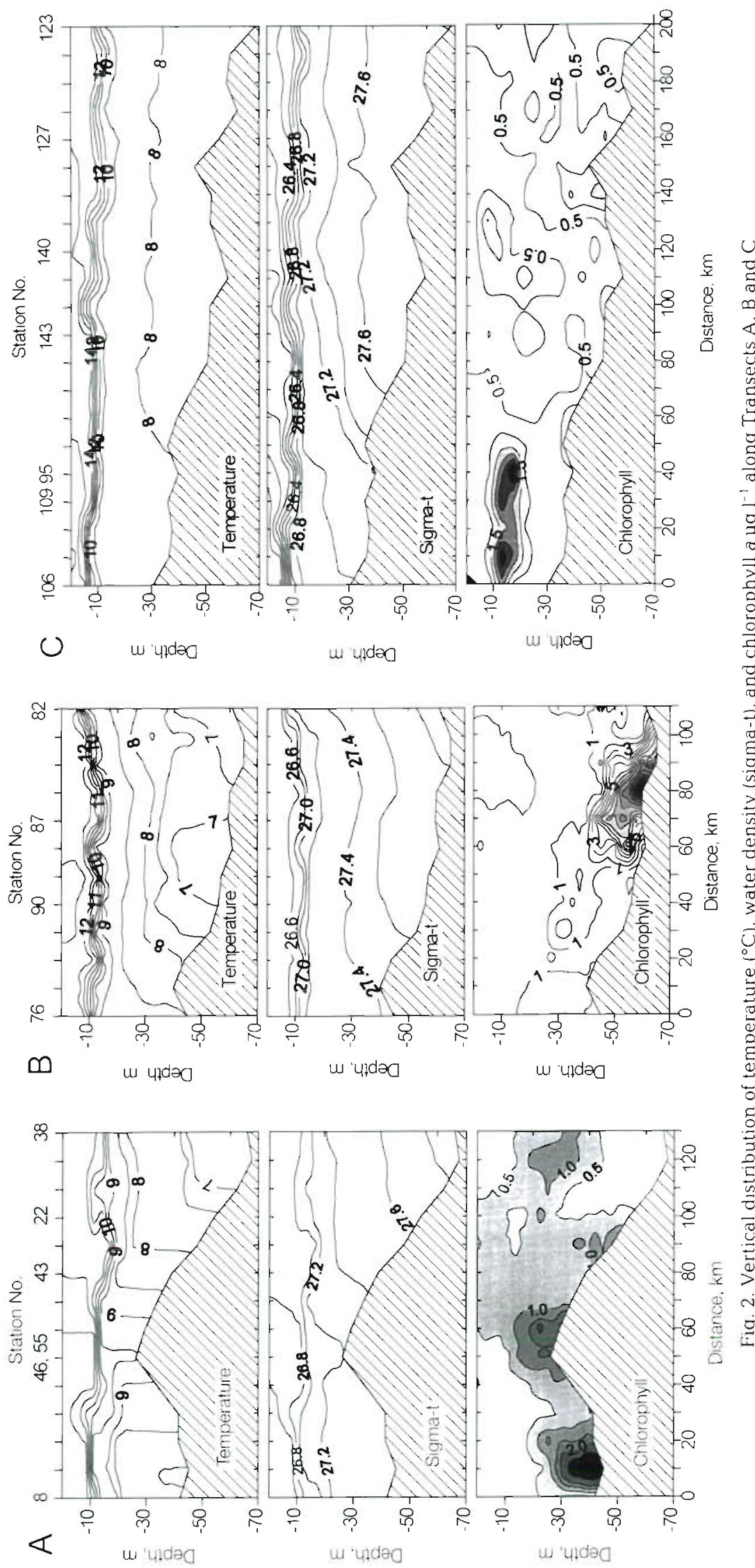

Transect $C$ was influenced by the less saline Jutland coastal current which created a front 40 to $60 \mathrm{~km}$ from the eastern border of this transect. In general the water column structure was determined by temperature differences, so variation in density (sigma-t) followed the temperature variation. The concentration of chl a was low in the surface mixed layer $(0.1$ to $0.5 \mu \mathrm{g}$ chl a $\mathrm{l}^{-1}$ ), whereas higher concentrations were recorded in bottom waters (Transects $A$ and $B$ ) or at the bottom of the thermocline (Transect C).

\section{Potential copepod prey}

The subsurface phytoplankton population comprised the major part of the depth integrated phytoplankton biomass (Fig. 3). The size fractionated samples, only taken at 2 depths along Transect $A$, showed that the subsurface phytoplankton community was dominated by somewhat larger cells than the surface community $[67 \pm 12 \%$ and $38 \pm$ $10 \%$ were larger than $11 \mu \mathrm{m}$ (mean \pm $\mathrm{SE}$ ), respectivelyl (Fig 4). Surface values show that the average cell size was bigger at Dogger Bank (Transect A) than at the 2 other transects where the $>11 \mu \mathrm{m}$ fraction of phytoplankton contributed $19 \pm 5$ and $23 \pm 2 \%$ for Transects $B$ and $C$, respectively. There were no differences in the species composition of the phytoplankton community within the area studied. The phytoplankton was composed of a mixture of small flagellates ( 2 to $5 \mu \mathrm{m}$ ), diatoms (Skeletonema costatum, Coscinodiscus spp.) and dinoflagellates (Dinophysis norvegica, D. acuta and Ceratium tripos).

The protozooplankton was dominated by ciliates. The obligate autotroph Mesodinium rubrum was the most abundant and comprised $40 \pm 14 \%$, $\mathrm{n}=20$ of the integrated biomass. The heterotrophic/mixotrophic ciliates were dominated by small, 20 to $40 \mu \mathrm{m}$, naked oligotrichs (Lohmaniella spp., Strombidium spp. and Strobilidium spp.) and the larger 50 to $70 \mu \mathrm{m} \mathrm{Cy}$ clotrichium spp.; tintinnids (Tintinnopsis spp. and Stenosomella spp.) were of 

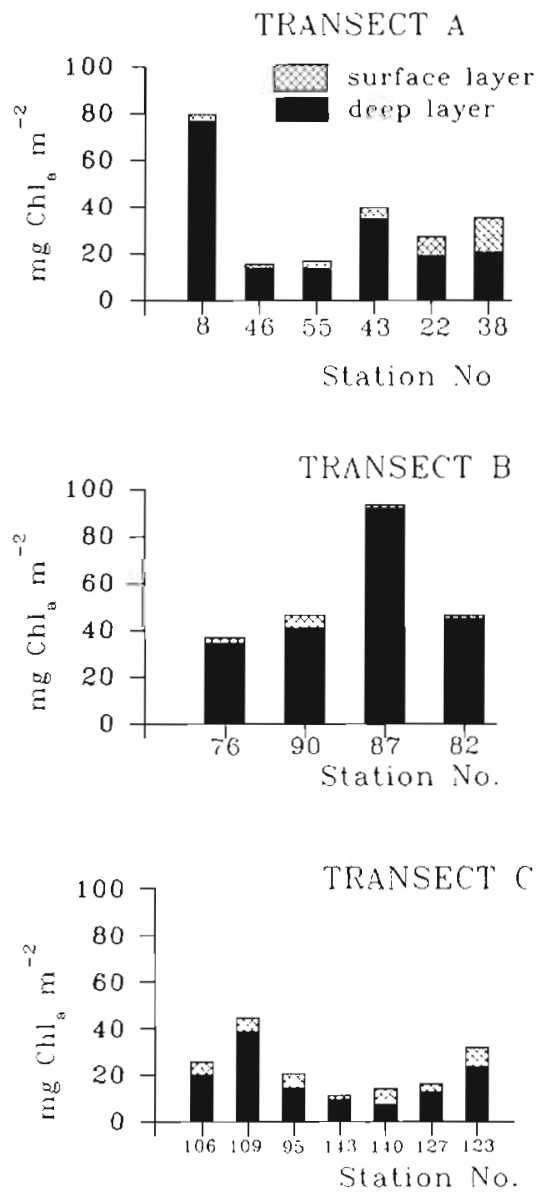

Fig. 3. Depth-integrated phytoplankton biomass above and below the thermocline/depth of maximum fluorescence along the 3 transects

minor importance. The heterotrophic dinoflagellates were dominated by thecate forms (Protoperidinium pellucidum, $P$. brevipes and $P$. depressum) contributing 14 $\pm 12 \%$ of the protozooplankton biomass, while naked forms (Gyrodiniun glaucum and G. spirale) only contributed $5 \pm 3 \%$. The depth integrated protozooplankton biomass ranged from 100 to $5000 \mathrm{mg} \mathrm{C} \mathrm{m}{ }^{-2}$ The biomass on Transects A and B was in the range 1000 to $2000 \mathrm{mg} \mathrm{C}$ $\mathrm{m}^{-2}$, while the biomass on Transect $\mathrm{C}$ was less than 1000 $\mathrm{mg} \mathrm{C} \mathrm{m}{ }^{-2}$ (Fig. 5).

\section{Copepod biomass, composition, fecundity and production}

Ten copepod genera or species were identified. Among them, Oithona spp., Paracalanus parvus, Temora longicornis, Acartia spp. and Calanus finmarchicus dominated the biomass. Their contribution to the depth integrated biomass is shown in Fig 6. O. similis made up the major part of the Oithona spp. biomass
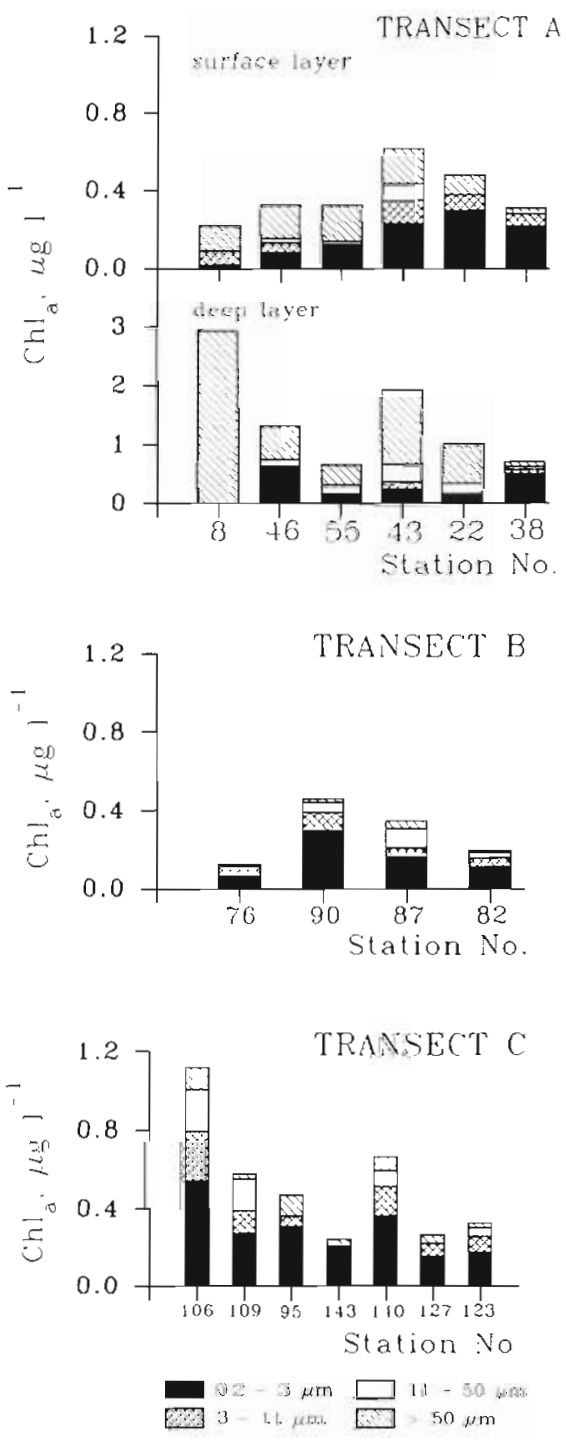

Fig. 4. Size distribution of the surface phytoplankton along the 3 transects. The size distribution below the thermocline is also shown for Transect $\mathrm{A}$

although a few $O$. plumifera and $O$. nana were observed in the samples. Within the area regional differences were observed in the species composition: Oithona spp. and $T$ longicornis were very abundant on and in the vicinity of Dogger Bank (Transect $A$ ) while Acartia spp. dominated on the coastal side of the front on Transect $C$. The deep stations in the northern part of Transects A and B and west of the front on Transect $C$ were dominated by Calanus spp., Metridia lucens and Pseudocalanus sp. (see 'Others' in Fig. 6).

The highest copepod biomass was found at the deep Calanus dominated stations towards the central North Sea (along Transects A and B) and on the western side of the front on Transect C. Except on the shallow Bank stations (Stn 46 and 55) where the biomass was homo- 

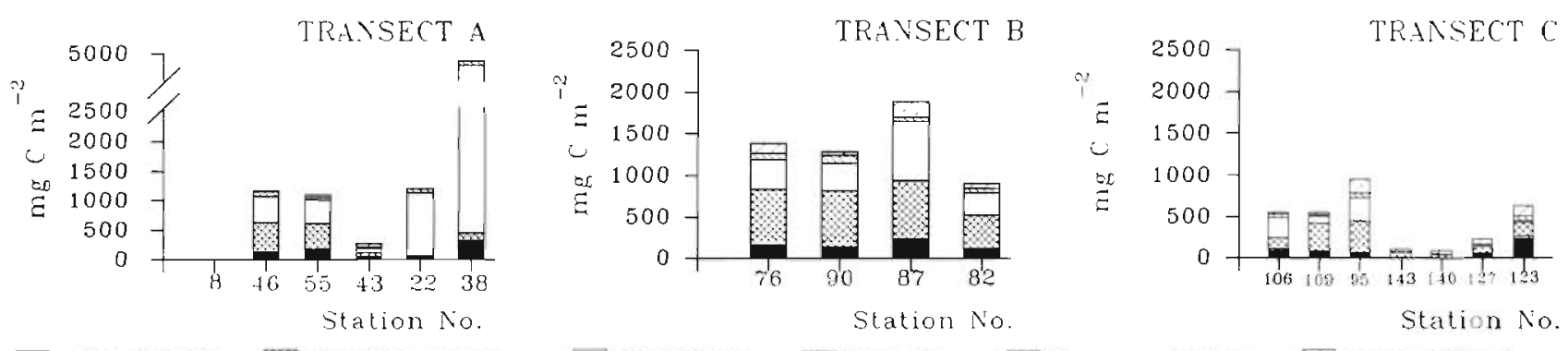

- Naked Oligotrichs Wrsodinesm mebrum

other cillates

(1⿴囗十) Tintinnids

3 Nakord dinorlagellates

therate dinorlagellatos

Fig. 5. Depth-integrated protozooplankton biomass calculated from discrete water samples along the 3 transects

geneous throughout the water column, about $80 \%$ of the copepod biomass was concentrated below the thermocline (Fig 6). Across the Dogger Bank stations (Transect A) Oithona spp. on average accounted for one-third $(33 \%)$ of the biomass both above and below the the:mocline and up to $50 \%$ on the bank proper. Along the 2 other transects it was less abundant (about 15\% in the surface layer and $10 \%$ below the thermocline).

Differences between the measured egg production rates of calanoid copepods and Oithona spp. were found. Maximum weight-specific egg production rates of Oithona spp. (Table 2) were lower and relatively constant within the area considered. Specific fecundity of calanoids (Table 3) was highly variable and a distinct spatial pattern was evident (Fig. 7). Across Dogger Bank (Transect A) the average egg production rate of the small calanoids and Calanus spp. was relatively low. Niuch higher specific egg production rates were found for the calanoid copepods along the 2 other transects. The egg production rate of small calanoids increased with distance from the Bank on Transect $B$ and at the coastal side of Transect $C$. There were no measurements of Calanus spp. egg production on Transect B (no females were available in surface waters since their biomass was concentrated in the deeper layer; Fig. 6). Their highest fecundity rates were measured in the stratified and deeper northern waters where, in contrast, very low egg production rates were measured for small calanoids.

The most complete series of data for examining the vertical distribution of copepod egg production was gathered for Oithona spp. (Fig. 8). Rates actually realized by Oithona were near constant or decreased with depth. However, if standardized to surface temperature rates (tempera-

TRANSECT A

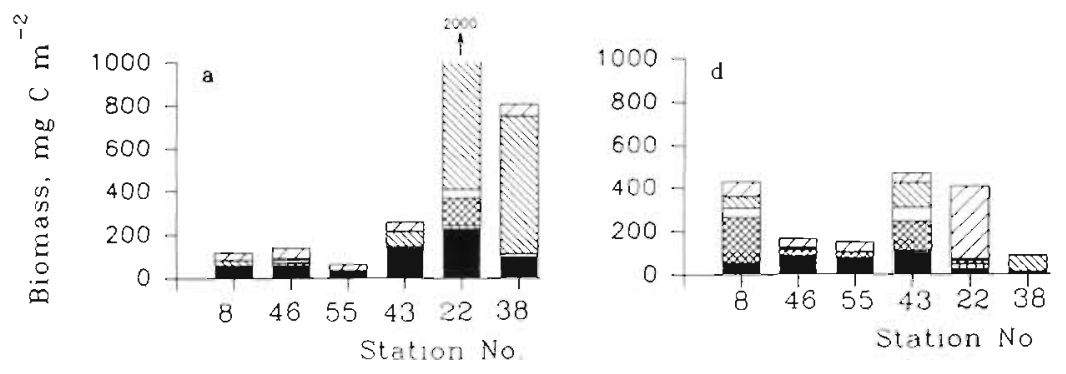

TRANSECT B
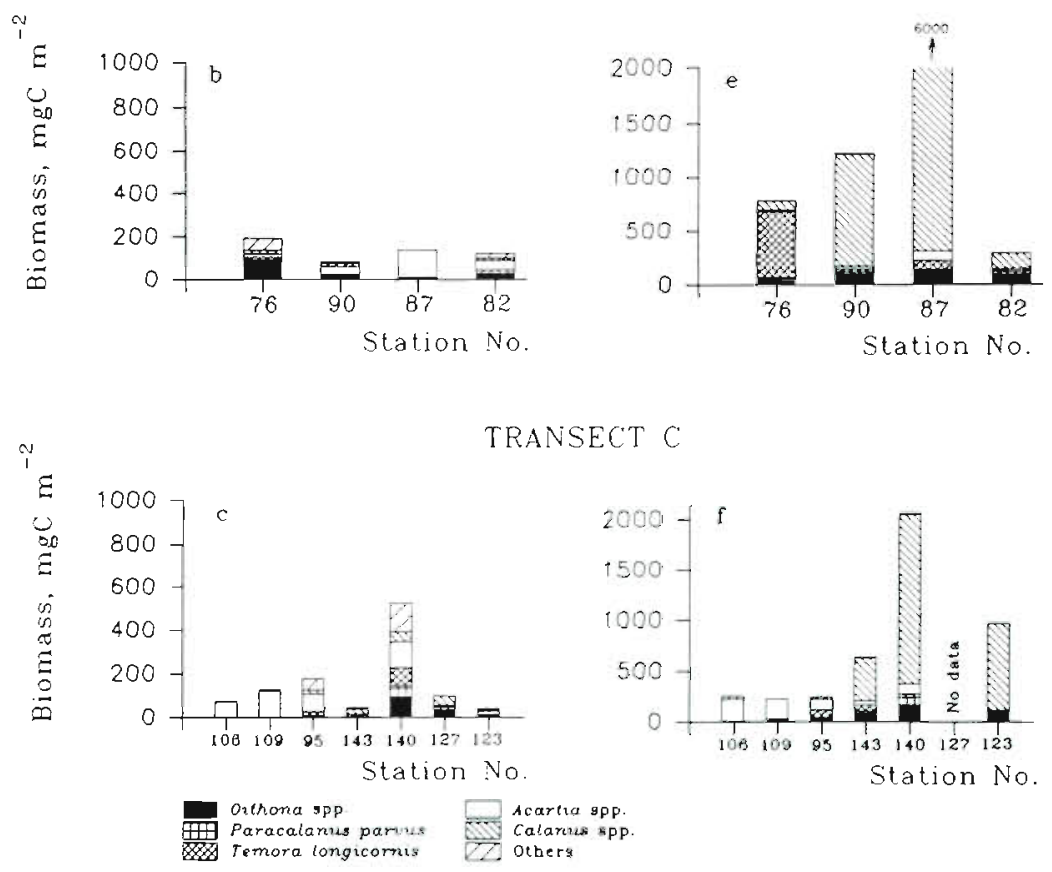

Fig. 6. Depth-integrated copepod biomass $(a, b, c)$ above and $(d, e, f)$ below the pycnocline, obtained from pump samples along the 3 transects 


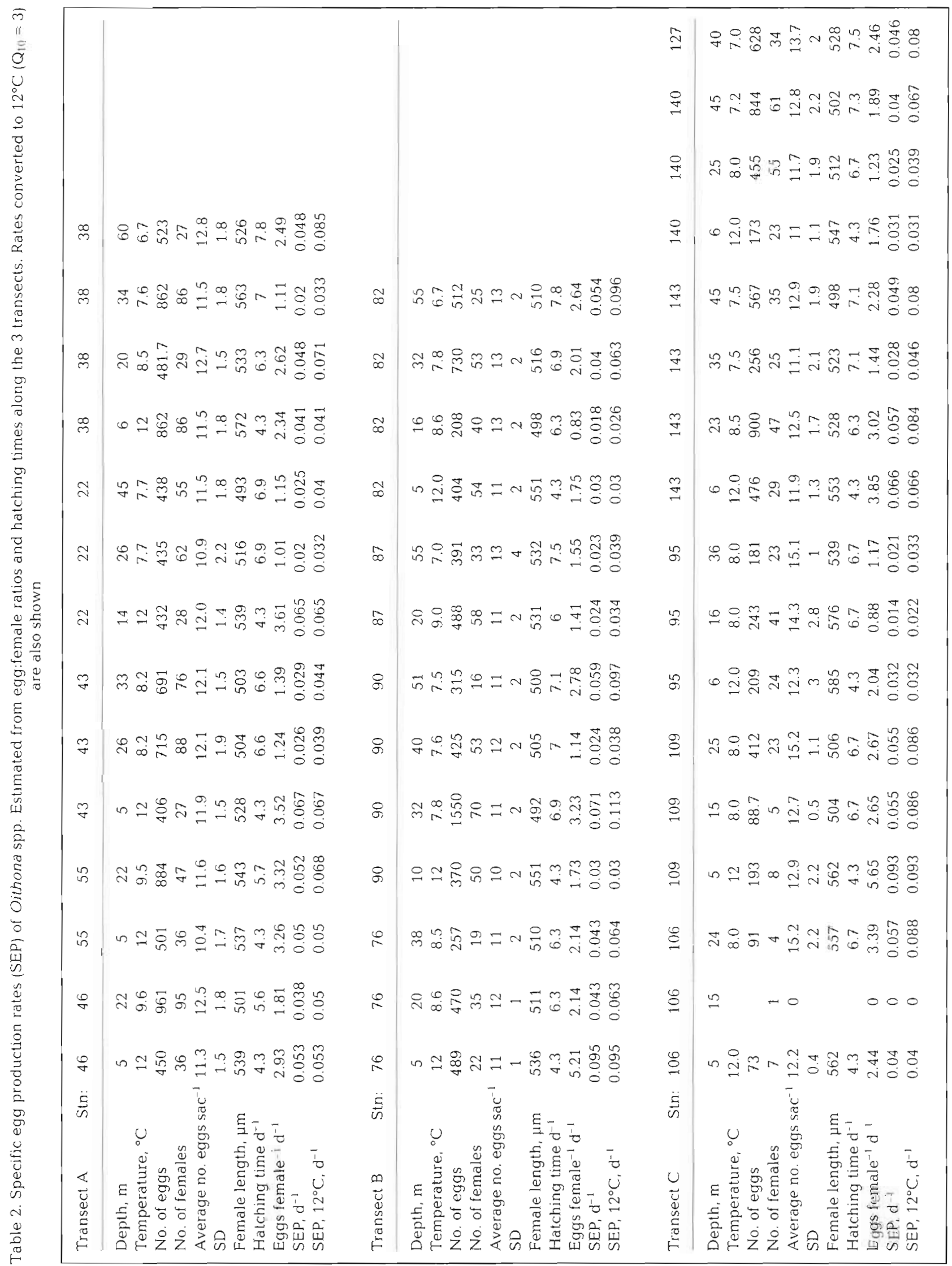


Table 3. Measured copepod egg production (in terms of egg female ${ }^{-1} \mathrm{~d}^{-1} \pm \mathrm{SD}$ and weight-specific rate, $\mathrm{d}^{-1}$ ) within the surface layer and at the maximum fluorescence depth (or below thermocline). Females were incubated in water from the sampling depth and at in situ temperature $\left(12\right.$ and $7^{\circ} \mathrm{C}$, respectively $)$. - no measurements. Number of experiments in parentheses

\begin{tabular}{|c|c|c|c|c|c|c|c|}
\hline Transect A & Stn: & 8 & 46 & 55 & 43 & 22 & 38 \\
\hline \multicolumn{8}{|l|}{ Surface } \\
\hline Calanus finmarchicus & \multicolumn{2}{|c|}{$0.005^{2.4}$} & - & - & $\begin{array}{l}0.0 \\
(1)\end{array}$ & $\begin{array}{l}26.9 \pm 25.8 \\
0.059\end{array}$ & $\begin{array}{l}0.3 \pm 0.8 \\
0.001\end{array}$ \\
\hline Centropages typicus & \multicolumn{2}{|c|}{$0.043^{19.7}$} & - & $\begin{array}{l}48.1 \pm 42 \\
0.106 \quad \text { (4) }\end{array}$ & - & - & - \\
\hline Centropages hamatus & \multicolumn{2}{|r|}{-} & - & ${ }^{23.5}$ & - & - & - \\
\hline Pdididanus parvus & \multicolumn{2}{|c|}{$\begin{array}{c}6.1 \pm 2.9 \\
0.043 \quad(2)\end{array}$} & ${ }^{2.7}$ & $\begin{array}{c}7.0 \pm 2.5 \\
0.049\end{array}$ & - & $\begin{array}{c}4.4 \pm 0.6 \\
0.031\end{array}$ & $\begin{array}{l}5.4 \pm 3.8 \\
0.038 \quad(7)\end{array}$ \\
\hline Temora longicornis & \multicolumn{2}{|c|}{$\begin{array}{l}16.5=3.1 \\
0.050\end{array}$} & - & $\begin{array}{c}24.0 \\
0.072\end{array}$ & $17.7 \pm 5.2$ & $\begin{array}{l}- \\
-\end{array}$ & $\begin{array}{l}- \\
-\end{array}$ \\
\hline Acartia spp. & \multicolumn{2}{|c|}{$\begin{array}{c}2.3 \pm 4.1 \\
0.030 \quad(6)\end{array}$} & - & - & - & - & - \\
\hline \multicolumn{8}{|l|}{ Fluorescence maximum } \\
\hline Calanus finmarchicus & \multicolumn{2}{|r|}{ - } & - & - & $\begin{array}{l}0.0 \\
(2)\end{array}$ & $\begin{array}{l}14.4 \pm 9.5 \\
0.032 \quad 6)\end{array}$ & $\begin{array}{l}14.7 \pm 29.9 \\
0.032\end{array}$ \\
\hline Centropages typicus & \multicolumn{2}{|r|}{-} & $\begin{array}{l}0.0 \\
(1)\end{array}$ & - & - & - & - \\
\hline Centropages hamatus & \multicolumn{2}{|r|}{-} & - & $0.068 \quad(1)$ & - & - & - \\
\hline Paracalanus parvus & \multicolumn{2}{|r|}{-} & - & $\begin{array}{c}3.9 \pm 2.5 \\
0.027 \quad(5)\end{array}$ & - & $0.004^{0.5}$ & $\begin{array}{c}0.9 \pm 0.4 \\
0.006 \quad(4)\end{array}$ \\
\hline Temora longicornis & & $\begin{array}{l}5 \pm 2.5 \\
550 \quad(4)\end{array}$ & $\begin{array}{l}15.9 \pm 6.2 \\
0.048\end{array}$ & $\begin{array}{l}15.0 \pm 1.3 \\
0.045\end{array}$ & $\begin{array}{l}15.7 \pm 8.9 \\
0.047\end{array}$ & - & - \\
\hline Transect B & Stn: & & & 90 & & & 82 \\
\hline Calanus finmarchicus & & & & - & & & - \\
\hline Centropages typicus & & & & $\begin{array}{l}105 \pm 39.6 \\
0.231\end{array}$ & $\begin{array}{l}33 \\
0.0\end{array}$ & $\begin{array}{l}4.5 \\
(6)\end{array}$ & - \\
\hline Centropages hamatus & & & & - & 0.1 & & - \\
\hline Paracalanus parvus & & $\begin{array}{r}6.9 \\
0.04\end{array}$ & & $\begin{array}{l}15.0 \pm 3.6 \\
0.075 \quad(6)\end{array}$ & $\begin{array}{l}21 \\
0.1\end{array}$ & & $\begin{array}{l}13.6 \pm 2.8 \\
0.095\end{array}$ \\
\hline Temora longicornis & & $\begin{array}{r}7.4 \\
0.02\end{array}$ & & - & & & - \\
\hline Transect C & Stn: & 106 & 109 & 95 & 143 & 127 & 140 \\
\hline Calanus finmarchicus & & - & - & - & $\begin{array}{c}28.0 \\
0.062\end{array}$ & $\begin{array}{r}55 \\
0.121\end{array}$ & $\begin{array}{l}22.5 \pm 3.5 \\
0.050 \quad(2)\end{array}$ \\
\hline Centropages typicus & & - & - & $\begin{array}{c}77.0 \\
0.169\end{array}$ & - & - & - \\
\hline Centropages hamatus & & - & - & $\begin{array}{l}26.2 \pm 3.5 \\
0.105 \quad(2)\end{array}$ & - & - & - \\
\hline Paracalanus parvus & & - & $\begin{array}{c}26.7 \\
0.188 \quad(1)\end{array}$ & $\begin{array}{l}33.4 \pm 4.7 \\
0.234\end{array}$ & $\begin{array}{c}1.5 \pm 2.1 \\
0.011 \quad(2)\end{array}$ & $\begin{array}{c}2.9 \pm 1.3 \\
0.020\end{array}$ & $\begin{array}{l}0.4 \pm 0.5 \\
0.003 \quad(4)\end{array}$ \\
\hline Temora longicomis & & - & - & $\begin{array}{l}17.1 \pm 10.4 \\
0.051\end{array}$ & $\begin{array}{l}16.4 \pm 13.7 \\
0.049\end{array}$ & $\begin{array}{c}26.0 \\
0.078 \quad(1)\end{array}$ & 0.020 \\
\hline Acartia spp. & & $\begin{array}{l}4 \pm 11.1 \\
87\end{array}$ & $\begin{array}{c}11.0 \\
0.143\end{array}$ & $\begin{array}{l}21.3 \pm 5.2 \\
0.276 \quad(5)\end{array}$ & $0.020^{1.5}$ & - & - \\
\hline
\end{tabular}




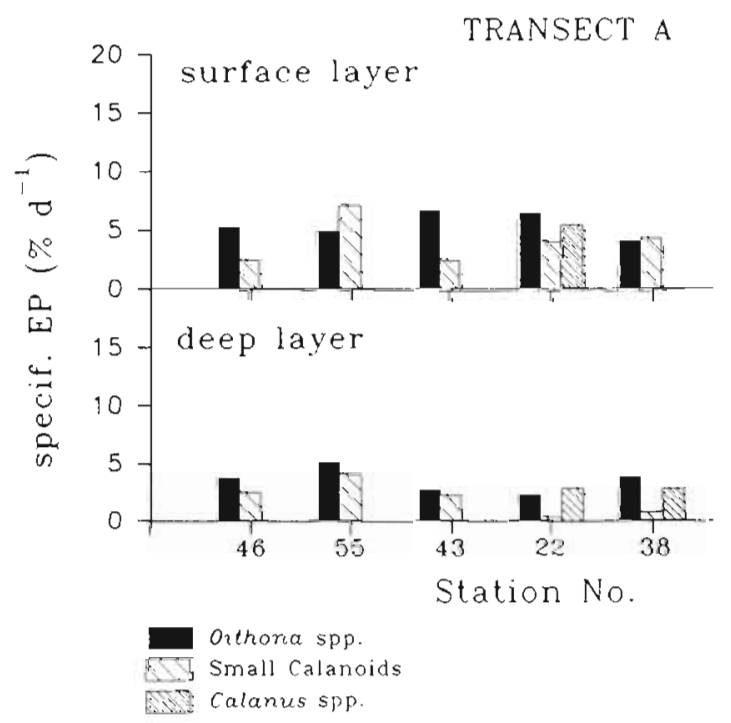

Fig. 7. Weight-specific egg production rate $\left(\%\right.$ body $\left.\mathrm{C} \mathrm{d}^{-1}\right)$ of Oithona spp., small calanoids and Calanus spp. along the 3 transects. Based on data shown in Tables 2 \& 3
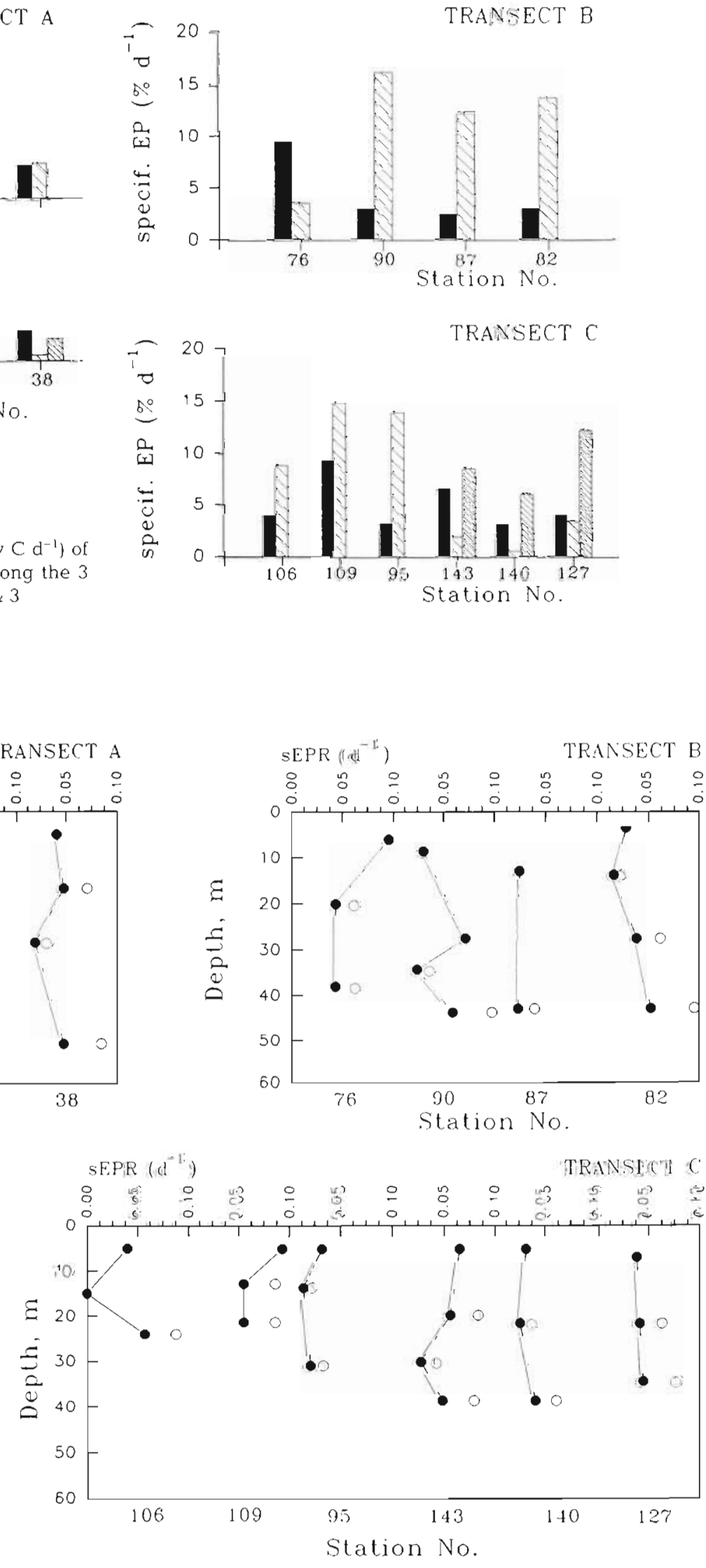

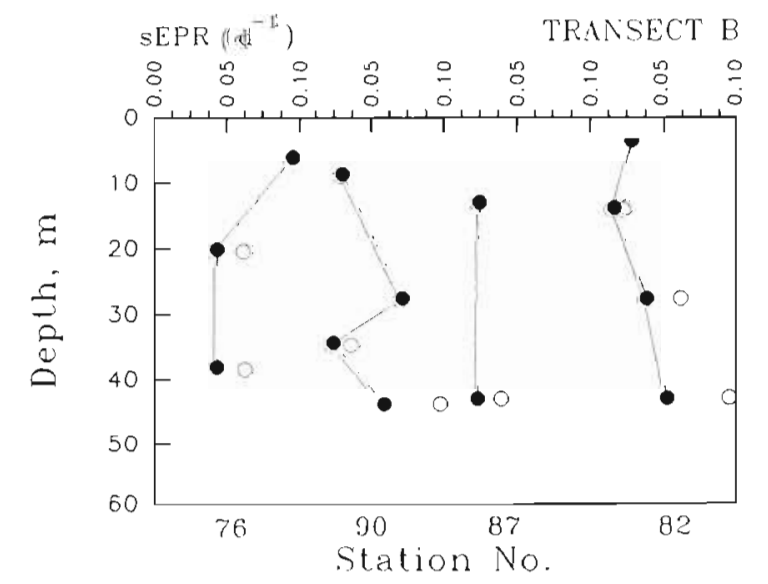

$\operatorname{sEPR}\left(\mathrm{d}^{-1}\right)$

RANSECT B
Fig. 8. Vertical pattern of the weight-specific egg production rate (sEPR) of Oithona spp. along the 3 transects. (O) In situ sEPR; (O) SEPR standardized to surface temperature $\left(12^{\circ} \mathrm{C}\right)$
TRANSECT A

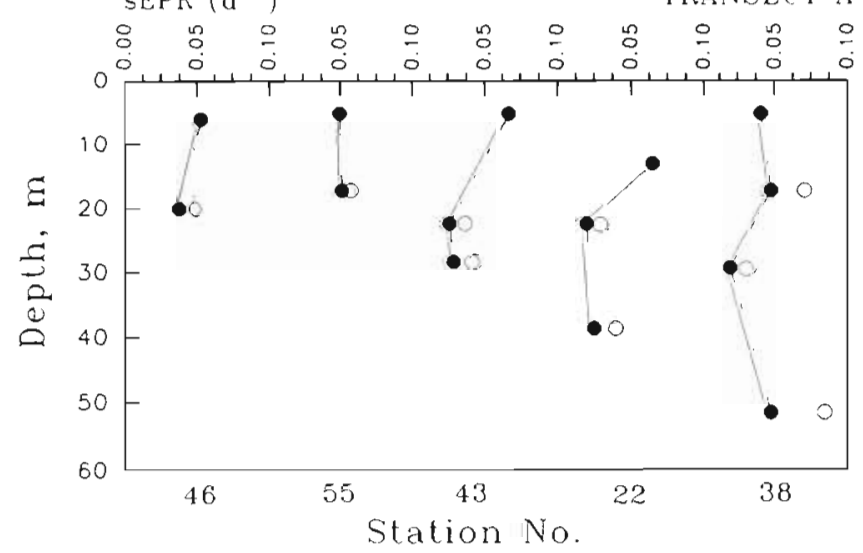


ture corrected rates by assuming $Q_{10}=3.0_{i}$ Kiorboe \& Sabatini 1995 and references therein) are considered, then Oithona spp. egg production was roughly constant throughout the water column or increased with depth. Information for calanoids was restricted to Transect A. The measurements of egg production in surface waters and below the thermocline also show higher temperature corrected fecundity rates in the deeper layer for most of the species (Table 3).

There was no coupling between egg production rate and the observed hydrography or phytoplankton distribution along Transects A and B. However, a response in the egg production rate was observed for Acartia spp. and Paracalanus parvus on Transect C, associated with the coastal front where their egg production rates increased 5 and 20 times, respectively (Table 3).

The relative contribution of Oithona spp. to total copepod production (Fig. 9) varied within the area studied Across Dogger Bank, Oithona spp. on average accounted for $47 \%$ of the total copepod production with a peak value of $70 \%$. Along Transects B and C, Oithona spp. was less important (18 and $8 \%$ respectively). The highest secondary production during this cruise was measured at the deep Calanus dominated stations on Transects $B$ and $C$

\section{Potential relationships between fecundity and food availability/composition}

In order to examine whether there was any differential response in the Oithona spp. versus calanoids' fecundity to the food environment a correlation analy- sis was performed. Paracalanus parvus was chosen as representative of calanoids since the most complete set of data was collected for this species. Only surface data were compared because the egg production measurements for $P$. parvus were too few $(n=3)$ in the deeper layer. Even though Oithona fecundity was not significantly correlated to any food item, a positive trend was found in the relation with all the protozooplankton prey while those with both fractionated and total chlorophyll were negative (Table 4). Moreover, the same trends can be observed when the data for the entire water column were pooled. The exactly reverse pattern was found for $P$. parvus, their rates in surface being significantly related to total chlorophyll concentration $(\mathrm{r}=0.70)$. These opposite patterns suggest fairly distinct feeding habits for both species, implying overall a preference of Oithona spp. for motile prey.

\section{Annual production of Oithona spp. in the North Sea}

Broadly, 2 major subregions can be distinguished in the North Sea on the basis of bathymetric and hydrographical characteristics: (1) the southern, relatively shallow area $(<50 \mathrm{~m})$ which includes Dogger Bank and surrounding waters; and (2) the northern, deeper area (>100 m) with a strong Atlantic influence. The annual patterns of copepod biomass, fecundity and resulting production within each of the 2 subregions are shown in Fig. 10. Total copepod biomass was highest in the northern subregion, primarily due to the occurrence of Calanus spp. and Pseudocalanus elongatus. The biomass of Oithona spp. was comparable or lower in the

Table 4. Coefficient of correlation ( $\mathrm{r}$ ) and level of significance for Oithona spp and Paracalanus parvus weight-specific egg production rate in surface waters (and within the entire water column for Oithona spp. only) versus potential food sources. n: number of observations; SEP: specific egg production rate; ns: not significant

\begin{tabular}{|c|c|c|c|c|c|c|c|c|c|}
\hline \multirow[t]{2}{*}{ SEP } & \multicolumn{4}{|c|}{ Chlorophyll a fraction } & \multicolumn{5}{|c|}{ zooplank } \\
\hline & $3-11 \mu \mathrm{m}$ & $11-50 \mu \mathrm{m}$ & $3-50 \mu \mathrm{m}$ & Total & Mesodinium & $\begin{array}{l}\text { Naked } \\
\text { ciliates }\end{array}$ & $\begin{array}{c}\text { Ciliate } \\
\text { total }\end{array}$ & $\begin{array}{c}\text { Naked } \\
\text { dinos }\end{array}$ & $\begin{array}{c}\text { Thecate } \\
\text { dinos }\end{array}$ \\
\hline \multicolumn{10}{|c|}{ Surface } \\
\hline \multicolumn{10}{|c|}{ Oithona spp. } \\
\hline r & -0.06 & -0.04 & -0.01 & -0.13 & 0.32 & 0.02 & 0.16 & 0.052 & 0.41 \\
\hline$n$ & 15 & 15 & 15 & 15 & 15 & 35 & 35 & 15 & \\
\hline $\mathrm{p}$ & ns & ns & ns & ns & ns & ns & ns & 0.05 & \\
\hline \multicolumn{10}{|c|}{ P. parvus } \\
\hline r & 0.24 & 0.53 & 0.49 & 0.70 & -0.07 & -0.20 & -0.28 & -0.48 & -0.22 \\
\hline $\mathrm{n}$ & 12 & 12 & 12 & 12 & 12 & 12 & 12 & 12 & 12 \\
\hline p & ns & ns & ns & 0.01 & ns & ns & ns & ns & ns \\
\hline \multicolumn{10}{|c|}{ Water column } \\
\hline \multicolumn{10}{|c|}{ Oithona spp. } \\
\hline$r$ & -0.05 & -0.06 & -0.07 & -0.18 & 0.23 & 0.01 & 0.02 & 0.12 & 0.14 \\
\hline n & 20 & 20 & 20 & 45 & 44 & 44 & 44 & 44 & 44 \\
\hline $\mathrm{p}$ & ns & ns & ns & ns & ns & ns & ns & ns & ns \\
\hline
\end{tabular}



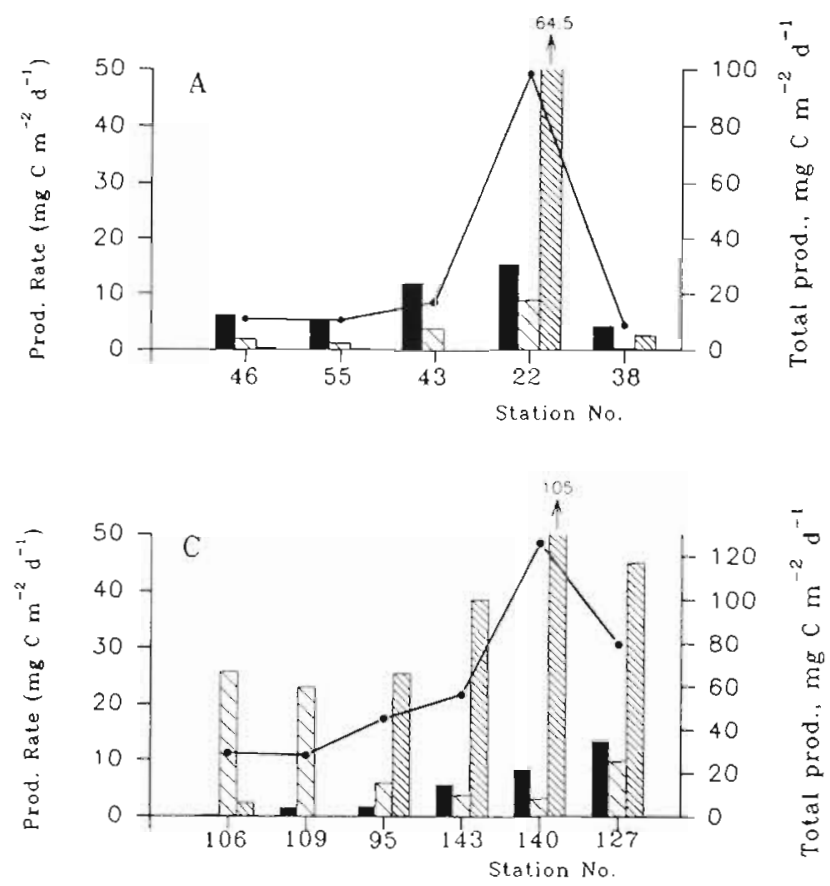

southern than in the northern region. However the relative contribution of Oithona to the standing stock of copepods on average was the same in both regions, 25 $\pm 3 \%$ (range 10 to $35 \%$ ) and $24 \pm 3 \%$ (range 7 to $39 \%$ ). In general, the highest weight-specific egg production rates were measured in the southern frontal area. The annual secondary production of the copepod com-

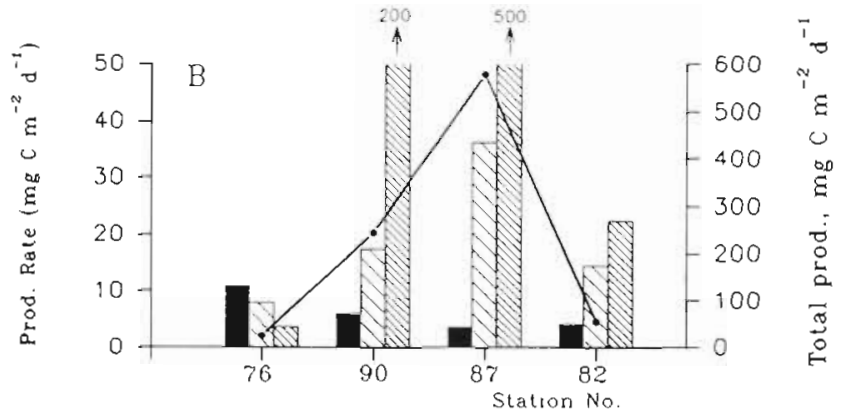

Fig. 9. Estimated total copepod production (solid line, $\mathrm{mg} \mathrm{C}$ $\mathrm{m}^{-2} \mathrm{~d}^{-1}$ ) and rates realized by Oithona spp. in comparison

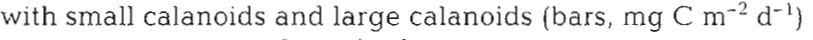
along the 3 transects

munity was estimated to be 5.6 and $14.3 \mathrm{~g} \mathrm{C} \mathrm{m}^{-2}$ for the southern and northern regions, respectively. The annual Oithona spp. production was about the same in both regions ( 2.2 and $1.8 \mathrm{~g} \mathrm{C} \mathrm{m}^{-2}$ ) while their relative importance compared to calanoids was quite different, with a contribution to the annual production of 40 and $13 \%$, respectively.
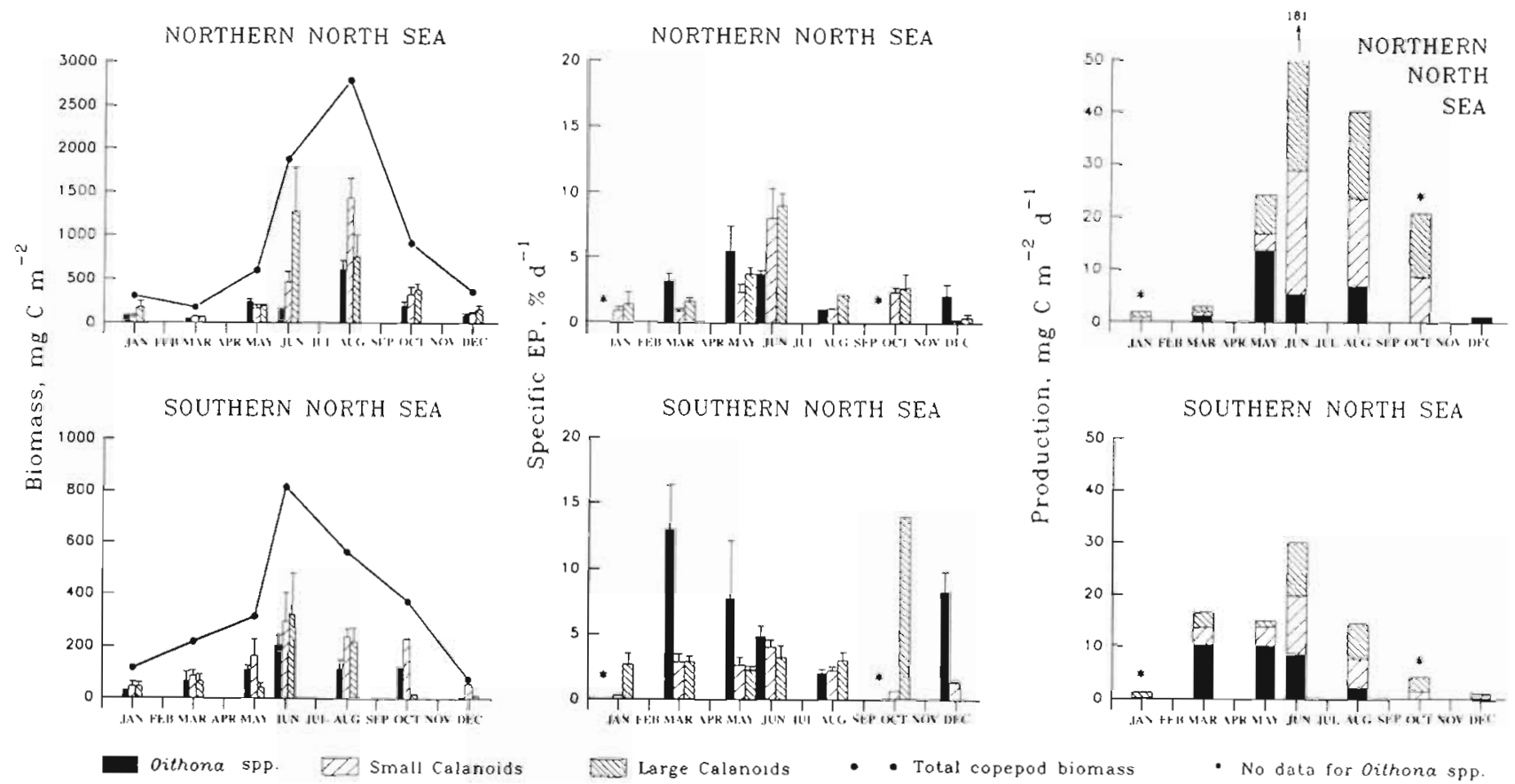

Fig. 10. Seasonal trends in the depth integrated copepod biomass (solid line, $\mathrm{mg} \mathrm{C} \mathrm{m}{ }^{-2}$ ), weight-specific egg production (\% body $\mathrm{C} \mathrm{d}^{-1}$ ) and secondary production ( $\mathrm{mg} \mathrm{C} \mathrm{m} \mathrm{m}^{-2} \mathrm{~d}^{-1}$ ) in the southern and northern North Sea. Sources of data in Table 1 


\section{DISCUSSION}

The egg production method used to estimate copepod production in the present investigation has previously been applied to free-spawning copepods, but may also be used for estimating production by the eggcarrying Oithona spp. The potential growth of juvenile cyclopoid copepods appears to be constant up to $\mathrm{C} 4$ (ca $0.20 \mathrm{~d}^{-1}$ at $15^{\circ} \mathrm{C}$ ) whereafter it decreases (Paffenhöfer 1993, Sabatini \& Kiørboe 1994). That means that one of the basic assumptions of the egg production approach is not fulfilled (Berggreen et al. 1988). However, we argue that this approach is still valid, since: (1) the maximum weight-specific egg production rate of $O$. similis $\left(0.10 \mathrm{~d}^{-1}\right.$ at $\left.15^{\circ} \mathrm{C}\right)$ approaches the maximum weight-specific growth rate of older copepodids (0.07 $\mathrm{d}^{-1}$ ) (Sabatini \& Kiørboe 1994); (2) the dominating species in the region studied was 0 . similis; and (3) the biomass of Oithona spp., as of copepods in general, is mostly made up of older stages (Krause \& Thrams 1983, Mullin 1988, Fransz et al. 1991). The egg:female ratio, which is potentially biased in freespawning copepods due to egg predation, sinking and advection, is not biased for the egg-carrying Oithona (Hay et al. 1991). In our samples, we found that normally 40 to $50 \%$ of the egg sacs were still attached to the females during counting and egg sacs of Oithona spp. lost during handling and fixation were easily distinguishable from those of the co-occurring, eggcarrying copepods (Pseudocalanus sp. and Microsetella norvegica).

Our estimates of annual copepod production for the North Sea, though conservative, are within the range reported in the literature from about 5 to $10 \mathrm{~g} \mathrm{C} \mathrm{m}^{-2}$ in the southern to at least $20 \mathrm{~g} \mathrm{C} \mathrm{m}^{-2}$ in the northern area of the North Sea (Fransz et al. 1991). Production of Oithona spp. in terms of annual $\mathrm{C} \mathrm{m}^{-2}$ was also within the range estimated for a few other localities of the North Sea as well as for other temperate areas (Table 5).

Our results show that the weight-specific egg production and daily production rates of Oithona spp. did not show as pronounced seasonal and spatial signals as observed for the co-occurring calanoid copepod genera. For example, there was no response to the increased phytoplankton biomass associated with the fronts on Transect C, as observed for Acartia spp. and Paracalanus parvus (Table 3). It was also apparent that the relative importance of Oithona spp. decreased from the shallow Dogger Bank area to the deeper northern stations. The horizontal difference in the relative importance of Oithona was also supported by our annual estimates for the 2 subregions of the North Sea. The relative contribution of Oithona to total copepod production is primarily determined by the spatiotemporal pattern of productivity of the community as a whole. In other words, the lower the total copepod production, the higher the relative importance of Oithona. This is further suggested by the few other estimates reported in Table 5 . The same seems to be the case when examining the production of Oithona spp. relative to calanoids on a temporal scale. As an example, in the southern Kattegat (Denmark) their relative contribution was 20 to $30 \%$ for most of the year, but decreased to $<5 \%$ when small calanoid species peaked (Fig. 11).

Copepod egg production rates are often measured only in surface samples; however, the high frequency of subsurface blooms in the southern North Sea (Riegmann et al. 1990, Nielsen et al. 1993, Munk \& Nielsen

Table 5. Annual copepod community production and relative contribution of Oithona spp. in selected areas

\begin{tabular}{|c|c|c|c|c|c|}
\hline Area & $\begin{array}{l}\text { Total production } \\
\left(\mathrm{g} \mathrm{C} \mathrm{m}^{-2} \mathrm{yr}^{-1}\right)\end{array}$ & $\begin{array}{r}\text { Oithona } \\
\left(\mathrm{g} C \mathrm{~m}^{-2} \mathrm{yr}^{-1}\right)\end{array}$ & spp. & Method & Source \\
\hline $\begin{array}{l}\text { Emerald Bank } \\
\text { (Scotian Shelf) }\end{array}$ & $\begin{array}{r}8.5 \\
1.5 .6\end{array}$ & $\begin{array}{l}1.4 \\
1.0\end{array}$ & $\begin{array}{r}13.2 \\
6.0\end{array}$ & $\begin{array}{l}\text { Mass-specific P/B ratios } \\
\text { Life-history analyses }\end{array}$ & $\begin{array}{l}\text { Tremblay \& Roff (1983) } \\
\text { McLaren et al. (1989) }\end{array}$ \\
\hline $\begin{array}{l}\text { Kattegat } \\
\text { (Denmark) }\end{array}$ & 10.2 & 1.7 & 16.6 & $\begin{array}{l}\text { Egg production approach } \\
\text { (egg:female ratios) }\end{array}$ & $\begin{array}{l}\text { Recalculated after } \\
\text { Kiørboe \& Nielsen (1994) }\end{array}$ \\
\hline $\begin{array}{l}\text { North Sea } \\
\text { Southern bight, coast } \\
\text { Southern bight, offshore }\end{array}$ & $\begin{array}{r}12-23 \\
5-15\end{array}$ & & & Temperature-dependent rates & Fransz \& Gieskes (1984) \\
\hline Central North Sea & 10 & & & Temperature-dependent rates & Fransz \& Gieskes (1984) \\
\hline Off Northumberland (UK) & $\begin{array}{c}20.2 \\
(10-44)\end{array}$ & -3.7 & 18.3 & $\begin{array}{l}\text { Temperature-dependent rates } \\
\text { (nauplii not considered) } \\
\text { Average over } 15 \mathrm{yr}\end{array}$ & Roff et al. (1988) \\
\hline $\begin{array}{l}\text { Northern North Sea } \\
\text { Southern North Sea }\end{array}$ & $\begin{array}{r}14.3 \\
5.6\end{array}$ & $\begin{array}{l}1.8 \\
2.2\end{array}$ & $\begin{array}{l}13.0 \\
40.0\end{array}$ & $\begin{array}{l}\text { Egg production approach } \\
\text { (egg:female ratios) }\end{array}$ & This study \\
\hline
\end{tabular}


KATTEGAT
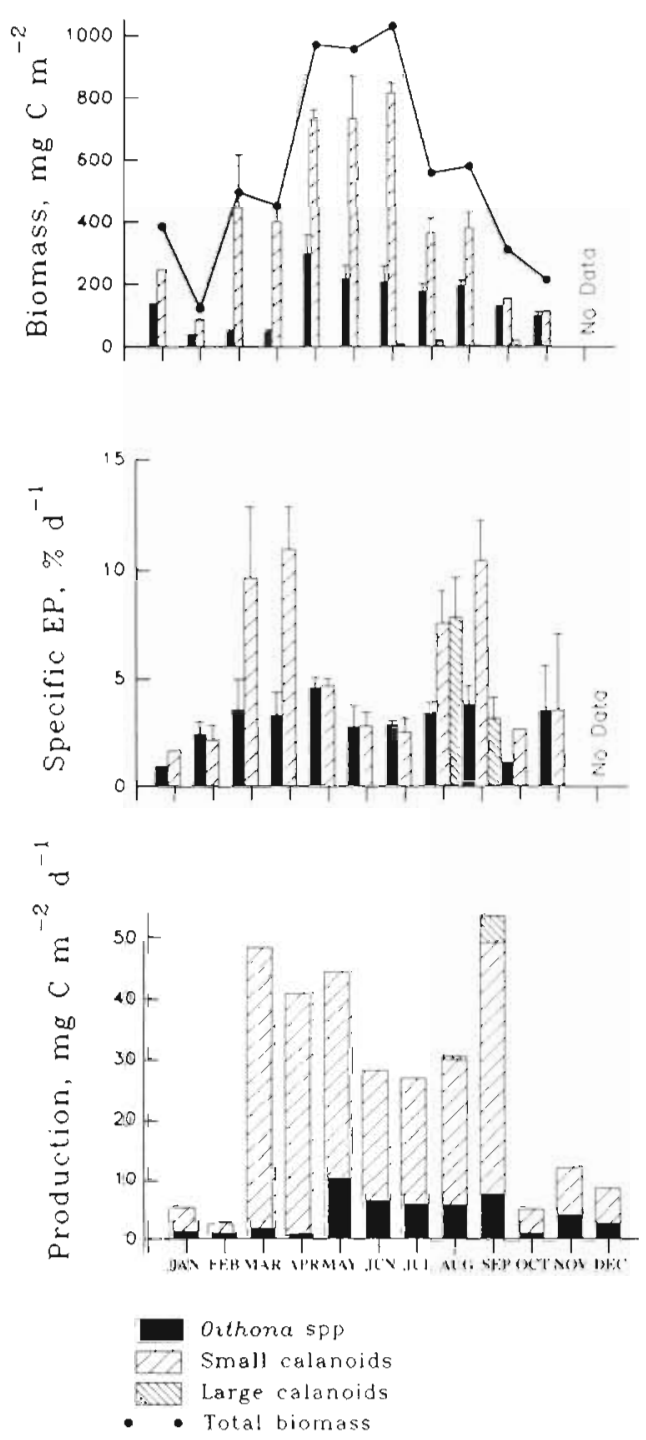

Fig. 11 Seasonal trends in the depth integrated copepod bio-

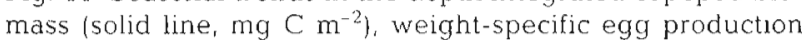
$\left(\%\right.$ body $\left.\mathrm{C} \mathrm{d}^{-1}\right)$ and secondary production ( $\mathrm{mg} \mathrm{C} \mathrm{m} \mathrm{C}^{-2} \mathrm{~d}^{-1}$ ) in the Kattegat (Denmark). Recalculated from Kiorboe \& Nielsen (1994)

1994), combined with food limitation of copepod populations during the summer, led us to estimate copepod production in 2 depth strata: surface mixed layer and subsurface fluorescence maximum. The egg production of Temora longicornis and Calanus spp. were the same or higher in water from the fluorescence peak, while Paracalanus parvus egg production was highest in the surface water. This difference might reflect the ability of the first 2 species to exploit the larger cells located below the pycnocline (Fig 4). The SEP of Oithona spp. was about the same throughout the water column (Fig. 8).
The potential food for the copepod community was dominated by diatoms, autotrophic and heterotrophic dinoflagellates and ciliates as observed on other summer cruises to the region (Nielsen et al. 1993). Food conditions were likely suitable for both calanoids and Oithona spp. in terms of particle size. Adults of O. simllis can effectively utilize food particles from 8-10 $\mu \mathrm{m}$ up to $35-40 \mu \mathrm{m}$ while nauplii can ingest flagellates as small as 2-5 $\mu \mathrm{m}$ (Eaton 1971, Drits \& Semenova 1984), overlapping thus the particle size range of calanoids

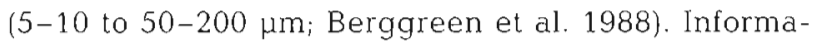
tion on in situ feeding patterns of cyclopoids is scarce and still quite controversial. Cyclopoid feeding mechanisms appear to be different from and more complex than those of many calanoids (Turner 1986, Paffenhöfer 1993, González \& Smetacek 1994). However, we found evidence (opposite trends in the correlation coefficients, $r$; Table 4) suggesting that $O$. similis preferred motile prey, in contrast to Paracalanus parvus, in which specific egg production rate was significant correlated to the chlorophyll concentration (Table 4). Oithona's preference for motile prey is supported by observations by Uchima \& Hirano (1986) who found that juvenile $O$. davisae only grew and survived on motile food particles. This also suggests that different behaviours are involved in the feeding of the 2 species This assumption is supported by laboratory studies on feeding behaviour where it has been shown that Oithona do not generate a feeding current; the encounter with food will depend on the signal provided by the food particle (Paffenhöfer 1993). P. parvus, on the other hand, is a slow-moving suspension feeder adapted for small prey organisms (Tiselius \& Jonsson 1990) and thus it can better take advantage of small non-motile phytoplankton cells.

The importance of Oithona spp. compared with calanoid copepods on Dogger Bank proper is actually due to the low biomass of calanoid species rather than to a particularly high biomass/production of Oithona. The egg-carrying strategy of Oithona may represent a clear advantage in comparison to broadcast spawning species in this particular area. Most of the calanoids release their eggs freely into the water and they often sink to the bottom where they lie until hatching. These eggs may constitute a supply of food for the large biomass of suspension feeding benthos occurring on the Bank (Duineveld et al. 1987), and thus, the recruitment of calanoids will be negatively affected. High mixing rates at the shallow Bank assure a frequent replacement of the water above the benthos that might favour, additionally, the consumption of eggs by suspension feeders. Therefore, the likely inadequate food conditions for calanoid species, which in turn translates into the lower specific fecundity rates realized across Dogger Bank, and potentially their high egg (predation) 
mortality, might explain the dominance of Oithona spp. in the area.

In summary, it appears that Oithona spp. production is less variable in time and space than that of the cooccurring calanoid genera. This may be due to the fact that Oithona spp. are specialized to feed on particles which are within the lower part of the food size spectrum for the copepods, likely small protozooplankton, but more important, normally available as related to microbial production. In contrast, most of the calanoid species depend on larger phytoplankton that occur in relatively short blooms or at oceanographic discontinuities. This has the advantage of allowing Oithona to maintain stable populations almost continuously

Though this is overall in accordance with Paffenhöfer's (1993) hypothesis for cyclopoids in general, it may not be related to their presumed metabolic 'slowness', as he argued. It would rather be a matter of lifecycle strategy, as the potential seems to exist, in Oithona at least, to reach growth and development rates as high as those of many calanoid species (Kiørboe \& Sabatini 1994, Sabatini \& Kiørboe 1994).

On account of the above, it can be speculated that Oithona is associated to microbial food webs and, therefore, its occurrence and productivity patterns are more stable than those of calanoids. Oithona might act as a link between smaller phytoplankton and/or small protozooplankton and larger zooplankton and fish larvae. It follows that their populations may constitute a currently available food item for fish larvae and planktivorous fishes, becoming a key species in areas or seasons where conditions are disadvantageous for calanoid copepods.

Acknowledgements. This work was supported by grants from Danish Natural Science Research Council grant no. 11-04201 to T.G.N. and from the Argentinean Science Research Council (Consejo Nacional de Investigaciones Científicas $y$ Técnicas, JUN91/Res. 8) and the Commission of European Communities (B/I1'-913134) to M.S. We thank Dan Conley, Benni Hansen and Thomas Kiørboe for critically reading the manuscript. We are indebted to the captain and crew of RV 'Dana' for help with sampling and we appreciate technical assistance by Jack Melbye and Alice Christoffersen.

\section{LITERATURE CITED}

Berggreen UC, Hansen B, Kiorboe T (1988) Food size spectra, ingestion and growth of the copepod Acartia tonsa during development: implications for determination of copepod production. Mar Biol 99:341-352

Cohen RE, Lough RG (1983) Prey field of larval Clupea harengus on a continental shelf spawning area. Mar Ecol Prog Ser 10:211-222

Daan N, Bromley PJ, Hislop IGR, Nielsen NA (1990) Ecology of North Sea fish. Neth J Sea Res 26:343-386

Drits AV. Semenova TN (1984) Experimental investigations of the feeding of Oithona similis Claus. Oceanology (USSR) 24:755-759 (English translation)
Duineveld GC, Künitzer A, Heyman RP (1987) Amphiura fillformis (Ophiuroidae: Echinodermata) in the North Sea. Distribution, present and former abundance and size composition. Neth J Sea Res 21.317-329

Eaton JM (1971) Studies on the feeding and reproductive biology of the marine cyclopoid copepod Oithona similis Claus. PhD thesis, Dalhousie University

Edler L (1979) Recommendations for marine biological studies in the Baltic Sea. Baltic Mar Biologists Publ 5:1-38

Fransz HG, Colebrook JM, Gamble JC, Krause M (1991) The zooplankton of the North Sea. Neth J Sea Res 28 (1/2):1-52

Fransz HG, Gieskes WWC (1984) The unbalance of phytoplankton and copepods in the North Sea. Rapp PV Reun Cons Int Explor Mer 183:218-225

Fransz HG, Gonzalez HE (1995) The production of Oithona similis (Copepoda: Cyclopoida) in the Southern Ocean. ICES J Mar Sci 52:549-555

González HE, Kurbjeweit F, Bathmann UV (1994) Occurrence of cyclopoid copepods and faecal materal in the Halley Bay region, Antarctica, during January-February 1991 Polar Biol 14:331-342

Hay SJ, Kiørboe T, Matthews A (1991) Zooplankton biomass and production in the North Sea during the autumn Circulation Experiment, October 1987-March 1988. Cont Shelf Res 11(12):1453-1476

Hopkins TL, Torres JJ (1989) Midwater food web in the vicinity of a marginal ice zone in the western Weddell Sea. Deep Sea Res 36:543-560

Hundahl $H_{1}$ Holck J (1980) A new in situ fluorometer for detection of Rhodamine B and chlorophyll. Report No. 42, Inst of Physical Oceanography, Univ of Copenhagen, p 145-154

Huntley M. Lopez MDG (1992) Temperature dependent growth production of marine copepods: a global synthesis. Am Nat 140:201-242

Jespersen AM, Christoffersen K (1987) Measurement of chlorophyll-a from phytoplankton using ethanol as extraction solvent. Arch Hydrobiol 80:445-454

Kane J (1984) The feeding habits of co-occurring cod and haddock larvae from Georges Bank. Mar Ecol Prog Ser 16: $9-20$

Kiørboe T, Møhlenberg F, Riisgaard HU (1985) In situ feeding rates of planktonic copepods: a comparison of methods. J Exp Mar Biol Ecol 88:67-81

Kiørboe T, Nielsen TG (1990) Effect of wind stress on vertical water column structure, phytoplankton growth and productivity of planktonic copepods. In: Barnes M, Gibson NR (eds) Trophic interactions in the marine environment. Proc 24th Eur Mar Bıol Symp. Aberdeen Univ Press, Aberdeen, p 28-40

Kiørboe I, Nielsen TG (1994) Regulation of zooplankton biomass and production in a temperate, coastal ecosystem. I. Copepods. Limnol Oceanogr 39:493-507

Kiørboe T, Sabatini M (1994) Reproductive and life-cycle strategies in egg-carrying cyclopoid and free-spawning calanoid copepods. J Plankton Res 16:1353-1366

Kiorboe T, Sabatini M (1995) The scaling of fecundity, growth and development in planktonic copepods. Mar Ecol Prog Ser 120:285-298

Krause M. Thrams J (1983) Zooplankton dynamics during FLEX 76. In: Sundermann J, Lenz W (eds) North Sea dynamics. Springer Verlag. Berlin, p 632-661

Kuwara A, Suzuki S (1984) Diurnal changes in vertical distribution of anchovy eggs and larvae in the western Wakasa Bay. Bull Plankton Soc Japan 50:1285-1292

McLaren IA, Tremblay MJ, Corkett CJ, Roff JC (1989) Copepod production on the Scotian Shelf based on life-history analy- 
sis and laboratory rearing. Can J Fish Aquat Sci 46:560-583

Mitamı 1 (1988) Food habits of Japanese anchovy in the shırasu fishing ground within Sagami Bay. Bull Plankton Soc Japan 54:1859-1865

Mullin MM (1988) Production and distribution of nauplii and recruitment variabllaty - putting the pieces together. In: Rothschild J (ed) Toward a theory on biological-physical interactions in the World Ocean. Kluwer Academic Press, New York, p 297-320

Munk P (1993) Differential growth of larval sprat Sprattus sprattus across a tidal front in the eastern North Sea. Mar Ecol Prog Ser 99:17-27

Munk P, Nielsen TG (1994) Trophodynamic of the plankton community at the Dogger Bank: predatory impact by larval fish. J Plankton Res 16(9):1225-1245

Nielsen TG, Lokkegărd $B$, Richardson $K$, Pedersen FB, Hansen L (1993) The structure of the plankton communitues in the Dogger Bank area (North Sea) during a stratified situation. Mar Ecol Prog Ser 95:115-131

Nielsen TG, Richardson K (1989) Food chain structure of the North Sea plankton communities: seasonal variations of the role of the microbial loop. Mar Ecol Prog Ser 56:75-87

Nishiyama T. Hirano K (1985) Prey size and weight relations in larval walleye pollock (Theragra chalcogramma). Bull Plankton Soc Japan 32:45-59

Ohtsuka S, Furkuura Y. Go A (1987) Description of a new species of Tortanus (Copepoda: Calanoida) from Kuchinoerabu Island. Kyushu, with notes on its possible feeding mechanisms and in situ feeding habits. Bull Plankton Soc Japan 34:53-63

Oresland V (1990) Feeding and predation of the chaetognath Eukronia hamata in Gerlache Strast, Antarctic Peninsula. Mar Ecol Prog Ser 63:201-209

Paffenhöfer GA (1993) On the ecology of marine cyclopoid copepods (Crustacea, Copepoda, Cyclopoida). J Plankton Res 15:37-55

This article was submitted to the editor
Peterson WT, Tiselius P. Kiorboe T (1991) Copepod egg production, moulting and growth rates, and secondary production, on the Skagerrak in August 1988. J Plankton Res 13:131-154

Riegmann R, Malschaert H, Colijn F (1990) Primary production of phytoplankton at a frontal zone located at the northern slope of the Dogger Bank (North Sea). Mar Biol 105:329-336

Roff JC, Middlebrook K, Evans K (1988) Long-term variability in North Sea zooplankton off Northumberland coast: productivity of small copepods and analysis of trophic interactions. J Mar Biol Ass UK 68:143-164

Sabatinu M, Kiorboe K (1994) Egg production, growth and development of the cyclopoid copepod Oithona similis. J Plankton Res 16(19):1329-1351

Strickland JD, Parsons TR (1972) A practical handbook of seawater analysis. Bull Fish Res Bd Can 167

Tiselius P, Jonsson PR (1990) Foragıng behaviour of six calanoid copepods: observations and hydrodynamic analysis. Mar Ecol Prog Ser 66:23-33

Tremblay MJ, Roff JC (1983) Production estimates for Scotian Shelf based on mass specific P/B ratios. Can J Fish Aquat Sci 40:749-753

Turner JT (1986) Zooplankton feeding ecology: contents of faecal pellets of the cyclopoid copepods Oncaea venusta, Corycaeus amazonicus, Oithona plumifera and $O$. simplex from the northern Gulf of Mexico. Mar Ecol 7:289-302

Uchima U, Hirano R (1986) Food of Oithona davisae (Copepoda: Cyclopoidal and the effect of food concentration at first feeding on the larval growth. Bull Plankton Soc Japan 33:21-28

UNESCO (1968) Monographs on oceanographic methodology. No 2. Zoologic sampling. UNESCO, Paris

Viñas MD, Ramirez FC (in press) Gut analysis of furst feeding anchovy larvae from Patagonian spawning area in relation to food availability. Arch Fish Mar Res

Manuscript first received: October 4, 1995

Revised version accepted: April 3,1996 